\title{
Exploring Performance Based Practice of CSR in Sustaining the Relationship between Business and Society: A Literature Review
}

\author{
Chidi M. Ibe ${ }^{1}$, Wang Z. Min ${ }^{1}$, Kwek C. Ling ${ }^{2}$ \& D. S. K Yii ${ }^{1}$ \\ ${ }^{1}$ Faculty of Business and Information Science, UCSI University, Kuala Lumpur, Malaysia \\ ${ }^{2}$ Faculty of Accountancy, Business and Finance, UCTAR, Kuala Lumpur, Malaysia \\ Correspondence: Kwek Choon Ling, Faculty of Accountancy, Business and Finance, UCTAR, Kuala Lumpur \\ Campus, Jalan Genting Kelang, Setapak, 53300 Kuala Lumpur, Malaysia. E-mail: kwekcl@acd.tarc.edu.my
}

Received: October 8, 2014 Accepted: October 29, 2014 Online Published: February 12, 2015

doi:10.5539/ass.v11n5p181 URL: http://dx.doi.org/10.5539/ass.v11n5p181

\begin{abstract}
The evolution of thought in sustainable development theory often implies that societal contribution of businesses in the form of corporate social responsibility (CSR) leads to sustainable development in the relationship between business and society. However, most of the propositions made by CSR scholars have been described as being normative and prescriptive in nature. The implication of this is that the process through which outcomes are generated from the implementation of CSR lacks adequate exploration and has remained relatively unknown. To explore the problem noted above, a literature review was carried out. The need for a paradigm shift from responsiveness paradigm to a performance based paradigm in the practice of CSR was observed. A performance based paradigm entails the generation of expected outcomes from the implementation of CSR through creating value alignment between business' values and stakeholders' values. From the literature review, three recommendations were generated. They include the need for a shift towards a performance based paradigm of CSR, need for the exploration of the interactive process in the relationship between business and society, and the need for more empirical based studies with focus on the interactive process of CSR as a means of predicting CSR outcomes.
\end{abstract}

Keywords: sustainable development, corporate social responsibility, corporate social responsiveness, corporate social performance, business and society, stakeholder theory, petroleum industry

\section{Introduction}

Theoretical efforts towards exploring the means through which sustainable development practices yield outcomes in the relationship between business and society has consistently pointed towards the need for businesses to ensure their profitability, while instilling social contributions to the society and preserving the environment through which natural resources are generated (Elkington, 2004; Carroll, 2009; Aras \& Crowther, 2009; Claydon, 2011). It has often been posited that the adherence to these sustainable practices by businesses enhance their relationship with the society (Aras \& Crowther, 2009; Elkington, 2004; Claydon, 2011). However, this position has been challenged by practical occurrences in the Nigerian petroleum industry.

Most of the Oil Companies in the Nigerian petroleum industry have adopted the practice of making socio-economic and environmental contributions towards enhancing their relationship with the society. Companies like Shell and ExxonMobil among others have embedded the principles of sustainable business practices in their policy frameworks. They function towards this direction by boasting about extensive efforts towards social, economic and environmental sustenance of their host-communities, while making profit (Ibok \& Mboho, 2011). However, these practices have not generated sustainable development for these Oil Companies and their host-communities. This is evident in the constant conflict between these Oil Companies and their host-community stakeholders, which results in disruption of business activities, and the destruction of lives and properties in the society (Chukwuemeka \& Aghara, 2010; Jike, 2004; Paki \& Ebienfa, 2011).

It has been noted that generating sustainable development goes beyond adherence to sustainable practices. It is observed as being beyond mere instilment of social, economic and environmental values by businesses (Bhattacharya, Korschen, \& Sen, 2009). It involves a deeper assessment of the process through which these contributions are made and a shift of focus towards a performance dominant paradigm in both theory and practice. 
In this paper, it is argued that the explanation of the dysfunctional phenomena in the Nigerian petroleum industry can be understood from the misalignment between advancements in theory and practice of sustainable development. In other words, this implies that Oil Companies in the Nigerian petroleum industry may adopt particular sustainable business practices that are theoretically obsolete and ineffective, which results in the unsustainability of business and society in the industry. A theoretical shift towards the adoption of a performance based disposition by companies in the industry is proposed. This is done with an extensive review of extant literature and the analysis of the existing practices in the Nigerian petroleum industry.

\section{Sustainable Development of Business and Society}

The realisation of the interwoven nature of business practices and societal sustenance has naturally increased the call for sustainable development. Business is defined as the collection of private and commercial oriented organizations that ranges in size, while society is defined as a community, nation or groups of people that share traditions, values, institutions and collective activities and interests (Carroll \& Budchholtz, 2012). History has shown that these two spheres greatly impact on each other, particularly in Nigeria.

The rise in discussions about the relationship between business and society was motivated by the widespread negative occurrences of disaster caused by Oil Companies in the Niger-Delta region of Nigeria. In the New York Times, it was noted that as many as 546 million gallons of oil is said to have been spilled into the Niger Delta seas over the last five decades, which is equivalent to nearly 11 million gallons a year (Nossiter, 2010). Nossiter (2010) further describes the incident as "the oil spews from rusted and aging pipes, unchecked by what analysts say is ineffectual or collusive regulation, and abetted by deficient maintenance and sabotage..." The result of this phenomenon is the loss of livelihood by community stakeholders, and a consistent rise in the frequency of protests and riots against Oil Companies by Nigerians in the Niger-Delta region. These protests and riots are increasingly threatening the sustainability of these Oil Companies.

The enormity of negative occurrences from business activities on society gave rise to the call for better control of businesses in order to ensure that they contribute positively to the society (Claydon, 2011). The rationale is that when businesses contribute positively to the society, society supports businesses to make profit, and the development of both business and society can be sustained. This is the tenet of sustainable development (SD). Unlike in the past, state interventionism in business activities has become increasingly obsolete, and the focus has shifted to the impact of businesses in society and society on business (Steurer et al., 2005).

The primary aim for scholarly focus on the relationship between business and society is to explore the means of creating cordiality between the business and society spheres. This has long been of paramount concern (Jones, 1983). To do this, it is important to first understand the nature of the relationship between business and society. One of the early efforts towards creating this understanding was made by Jones (1983). Jones (1983) noted that in trying to co-exist, business and society are faced with a complex system that is made up of several sub-systems as indicated in Figure 1 (Jones, 1983). The main subsystems include the economic, social and cultural sub-systems. These sub-systems are in continuous interaction with each other. The economic sub-system consists of institutions that carry out production and economic exchange, the political sub-system is made up of the government and regulatory bodies, and the cultural sub-system is made up of the family, community and value systems (Jones, 1983). In the course of their interactions, tensions arise between these sub-systems, which threaten to impede their coexistence. If these tensions are not well managed, they distort the interaction of business and society and impede their developments.

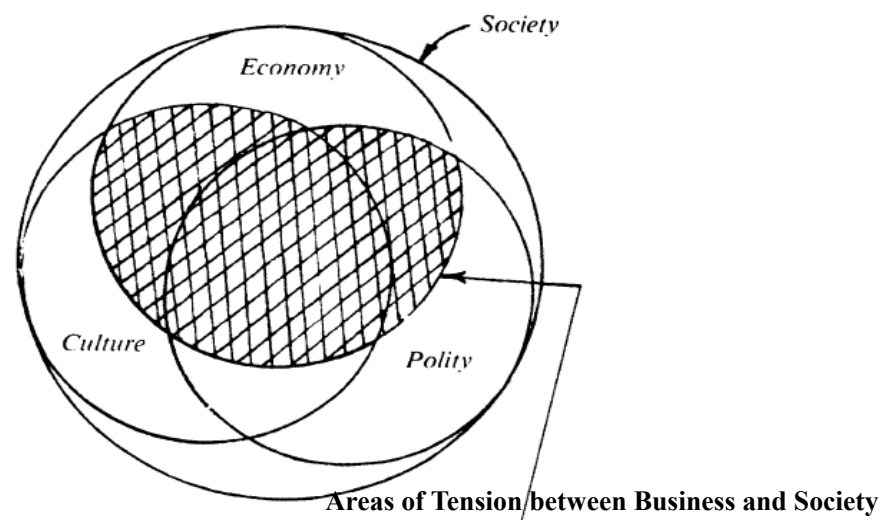

Figure 1. Relationship between business and society by Jones (1983) 
The means of managing this tension noted by Jones (1983) between business and society has been the focus of scholars since the 1920s. Specifically, scholars have proposed the concept of corporate social responsibility (CSR) as a means of resolving this tension (Clark, 1926; Berle 1932; Bernard, 1938; Kreps, 1940; Carroll, 1999; Aras \& Crowther, 2009; Freeman \& Hasnaoui, 2011; Claydon, 2011).

\section{Corporate Social Responsibility (CSR)}

Corporate social responsibility (CSR) concept implies the contributions made by businesses to society in a way that reflects their responsibility to the sustenance of society while making profit. However, this definition is very limited. Just like most social science concepts, the definition of CSR has generated extensive debates and varying definitions. To understand the CSR concept, it is paramount to understand the diversity in the definition of the concept.

The definition of CSR was traced back to the 1920s (Freeman \& Hasnaoui, 2011), where Clark (1926) saw it as the obligation of businesses in ensuring societal wellbeing. This was advanced by Berle (1932) who defined it as the obligation of businesses to support the disadvantaged segment of the society. The prevalent theme at those times (1920s to 1930s) was CSR as social obligation of business in the society. Social obligation implies that businesses have a responsibility that spans beyond their profit making motives, and includes a responsibility to a wider segment of the society (Carroll, 1999). However, the nature and extent of this obligation were not the concern of scholars within that period. They were more pre-occupied with creating the consciousness about the obligation that businesses owe to the society.

In 1953, Bowen defined CSR as being beyond the social obligation of business. It was seen as being the "Social Responsibility" of business. This marked a shift in the conception of CSR from being viewed as a social obligation to being seen as social responsibility (Carroll, 1999). What this implied was that businesses were not just morally bound to contribute to societal welfare; they are bound to make such contributions as a duty and part of their business existence.

In the early definitions noted above, the primary responsibility of businesses, which is profit generation, was not put into perspective. Eells (1956) and Levitt (1958) recognized this perspective. They saw CSR as being dependent upon the realization of economic objectives by businesses. In other words, they argued that businesses contribute to society when they have made profit. This gave rise to the concept of corporate philanthropy. However, this perspective was criticized for viewing business and society as distinct spheres of existence (Claydon, 2011).

Fredrick (1960) tried to address this criticism by defining CSR as the social responsibility that business has in overseeing the operation of an economic system that fulfils public expectation. With this definition, there was an attempt to capture the interwoven nature of the relationship between business and society, and most of all create a shift from CSR being viewed as corporate philanthropy to being viewed as corporate citizenship. This was further espoused by Friedman (1962), who saw CSR as the responsibility of businesses to their shareholders, which has a spiralling effect on general societal benefits. There was an attempt to balance the economic and social aims of business.

The scholarly attempts to balance economic and social objectives by businesses became more important as the inseparability of business and society became even more apparent. The survivability of business and society was increasingly seen as being determined by how they affect each other (Claydon, 2011). The occurrence of negative events, like the oil spill in the oil rich Niger-Delta region of Nigeria, enhanced the belief in the inseparability of business and society. Calls for the control of the activities of businesses heightened (Kakabadse, Rozuel \& Davies, 2005; Claydon, 2011). Global, continental and regional political institutions emerged to answer these calls (Claydon, 2011). This explains why through the 1970s to the 1980s, definitions that emerged reflected the concept of "Corporate Social Responsiveness" (Johnson, 1971; Carroll, 1979; Wartick \& Cochran, 1985; Epstein, 1987). In the 1990s, the scholars that championed the concept of social responsiveness as CSR were criticized for not going beyond the concept. Wood (1991) pointed out that showing social responsiveness does not necessarily imply the generation of performance from the implementation of CSR. She pointed out that the crafting of policies, as proposed by Wartick \& Cochran (1985) and Epstein (1987), does not necessarily transform into performance. Based on this shortcoming, CSR was redefined as consisting of principles, social responsiveness and social outcome (Wood, 1991). A performance perspective was added to CSR.

By the 2000s, attempts at defining CSR had greatly reduced because it was recognized as being a socially construed concept (Dahlsrud, 2006). It was conceived that the situation within which the concept exists greatly determines how it is defined (Freeman \& Hasnaoui, 2011). Gjolberg (2009) noted this in the definition of CSR as being context specific. Freeman \& Hasnaoui (2011) explored this context specific definition in their study of 
the definition of CSR in the UK, US, Canada and France, and found Gjolberg's (2009) definition to be valid. Amidst this realization, the theme of sustainable development remained dominant, and sustained scholarly efforts continued in trying to explore how businesses balance their economic objectives with social contributions (Aras \& Crowther, 2009; Claydon, 2011). This gave rise to the sustainable development theory in CSR.

\section{Sustainable Development Theory in CSR}

The sustainable development theory had existed within the political realm since the 1950s, and had been driven by societal struggle. It came as a political movement that spanned from the early environmental/ecological movement through the anti-war/anti-nuclear movement to the green movement and alternative economics movement (Estes, 1993). The alternative economics movement specifically reflected a shift to more economic related focus, within which the triple bottom line (TBL) emerged in the form of seeking for a change in the economic based policies that neglected the environment and people (Estes, 1993). Beyond the alternative economics movement, there existed the indigenous people's movement and the human rights movement in which further enhanced the argument for the implementation of social and environmental values along with economic values (Estes, 1993; Garriga \& Mele, 2004).

In terms of CSR, the sustainable development theory is based on the assessment of sustainable practices in the relationship between businesses and society such that economic, social and environmental values are preserved and developed (Elkington, 2004). This theory motivated a rise in models that aimed at explaining how CSR is to be implemented in order to generate sustainable development (Aras \& Crowther, 2009; Claydon, 2011). This is based on the premise that an effective implementation of social, economic and environmental contributions to society would lead to the sustainable development of both business and society (Elkington, 2004). Prominent among these models is the model of sustainable development by Aras \& Crowther (2009) as indicated in Figure 2.

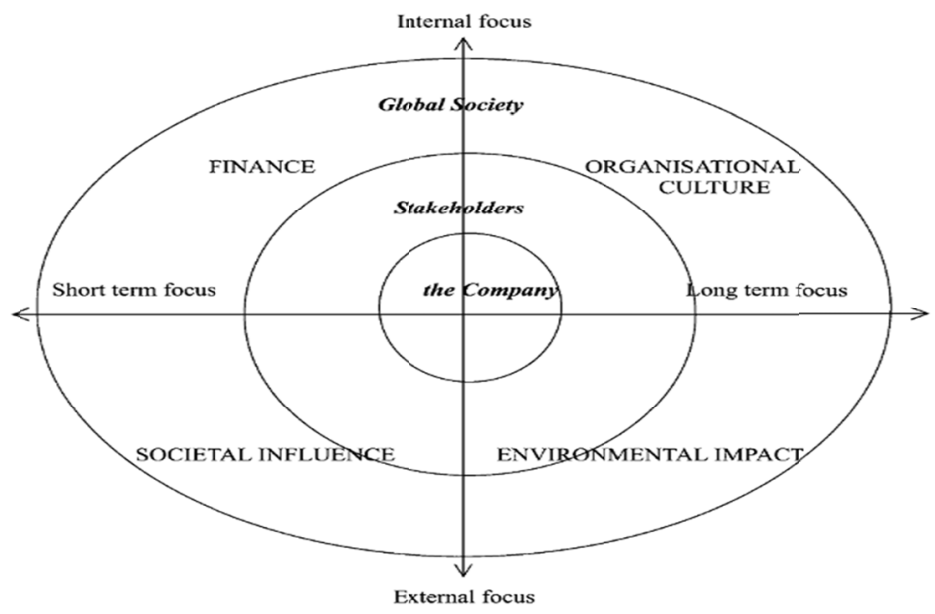

Figure 2. Model of sustainable development by Aras \& Crowther (2009)

The model in Figure 2 explicated the process of attaining sustainable development (SD) to include the creation of economic value, environmental maintenance, social contribution and adherence to societal values (Aras \& Crowther, 2009; Claydon, 2011). This was done through a look at environment, society, financial performance and organizational culture within short and long term contexts (Claydon, 2011). One important fact to note is that the model of sustainable development posited that the economic performance of businesses is dependent on their social and environmental performance and vice versa (Aras \& Crowther, 2009). This implies that the CSR contributions of business exist in a continuum (Claydon, 2011). In essence, if business is able to ensure that it contributes to the different components of the TBL, it can be rest assured that it will be sustainable along with the society within which it exists.

However, the above model was criticized for falling into the traditional trap of being normative and prescriptive in nature (Claydon, 2011). Like the models before it, the means of actually ensuring that economic value translates into social and environmental value were not captured in this model (Claydon, 2011). This raises questions about the performance component of the model because the means through which outcomes are generated was not explained. Claydon (2011) attempted to address this shortcoming by creating a consumer driven corporate responsibility (CDCR) model as indicated in Figure 3. 


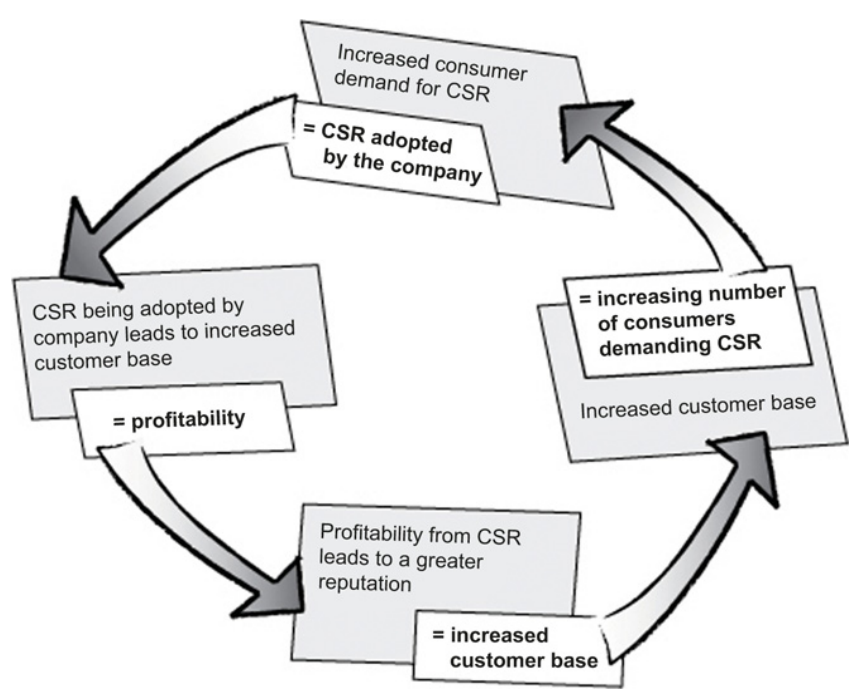

Figure 3. Consumer driven corporate responsibility (CDCR) model by Claydon (2011)

The CDCR model took a more in-depth approach in trying to propose the process in which sustainable development is achieved through CSR in the relationship between business and society. This model emerged out of the criticism of previous models in which included the model of sustainable development by Aras and Crowther (2009).

Claydon (2011) noted that in order to remain profitable, businesses need to adhere to consumers' demand for CSR. In doing this, businesses contribute to their long term profitability, while attaining short-term social goals. According to Claydon (2011), the CDCR model creates a win-win situation for businesses and society because consumers are satisfied, environment is maintained, businesses remain profitable and the requirements of other members of society are met. Focus is not just on consumers in this model; the requirements of customers and other stakeholders are expected to be met through businesses' interaction with society (Claydon, 2011).

The limitations in the CDCR model can be deduced from its underlying assumptions that raised critical observations. The assumption of increased consumer base due to the adoption of CSR by business and the translation of this process into profitability has been proven to be dependent upon context (Freeman \& Hasnaoui, 2011). The process through which these transformations take place was not enumerated and the contexts upon which such translations occurred remain ambiguous. Moreover, Bhattacharya et al. (2009) had noted that returns from CSR initiatives are not guaranteed because there are some integral processes and contexts that determine them. Besides, the CDCR model implied that the interaction between businesses and consumers would have a favourable impact on other stakeholders and the environment (Claydon, 2011). Again, the dynamics of context specificity in the conception and implementation of CSR, as noted in extant studies (Freeman \& Hasnaoui, 2011; Gjolberg, 2009), was not taken into consideration by Claydon (2011). Moreover, CDCR model did not show how the satisfaction of consumers and customers lead to the satisfaction of other stakeholders (i.e. shareholders', community, government, NGOs etc.). This means that this model did not highlight the performance based perspective of CSR. It is reflected in the fact that the process through which performance can be attained was not explained.

For the implementation of CSR to generate outcome, there is a need to go beyond the simplistic views that make scholars to emphasize that outcomes are just generated without actually exploring the means of generating these outcomes from the implementation of CSR and exploring how performance can be attained from such outcomes. This is a gap that needs to be filled in this area of study. Even more established models of sustainable development in CSR, like the pyramid of CSR (Carroll, 1979; 1991), did not address how the implementation of CSR by organizations leads to the generation of social and environmental good, and how these contributions translates to performance.

In more recent scholarly research, there is an emerging call for researchers to focus more on the process through which CSR translates into performance (Bhattacharya et al., 2009). This has become even more important because it has been noted that the implementation of CSR does not necessarily translate into performance (Bhattacharya et al., 2009). Logically, the implementation of CSR without the generation of performance is a 
pure waste of time. Performance, in the context of this paper, is the generation of sustainable development. This gap between CSR implementation and performance is evident in business practice. It is most visible in the Nigerian petroleum industry.

\section{CSR Implementation and Performance in the Nigerian Petroleum Industry}

Nigeria's major natural resource, crude oil, was found in the Arcuate Niger Delta region in 1956. The re-emergence of Nigeria's democracy in 1999 has made multinational oil companies to become more sensitive to their core corporate social responsibilities and sustainable development in the country (Aghalino \& Eyinla, 2009; Ibok \& Mboho, 2011).

ExxonMobil, for example, adopted the triple bottom line (TBL) practice as a means of making CSR contributions to their host-communities. They made a commitment towards preserving the environment in their host-communities, making socio-economic contributions, while ensuring business profit. They adopted sustainability reporting practices (ExxonMobil Corporate Citizenship Report, 2012) such as having series of social contributions in the form of provision of social amenities, creation of jobs, institution of health programs, adoption of innovative production techniques to avoid environmental degradation, increment of production capacity to improve national economy among others and work closely with the national oil spill detection and response Agency (NOSDRA) and their host-state's department of petroleum resources (DPR) to tackle oil spill occurences (Aghalino \& Eyinla, 2009).

Inspite of the changes noted above, the outcomes from these CSR initiatives implementation have generated outcomes that are not only surprising, but also challenges the tenets of theories and models in sustainable development studies. These Oil Companies are still being antagonized by the stakeholders in their host communities (Omotola, 2006, Jike, 2004; Opukri \& Ibaba, 2008; Aghalino \& Eyinla, 2009). In fact, the rate of protests in the Niger-Delta regions reached an unprecedented height with the show of desructive prowess by the emergent militant groups from the host-communities of these oil companies. The destruction of production resources (i.e. human and material), constant protest and theft of oil resources crippled the profitability of the businesses in the industry and caused untold destruction to the societies within which they exist.

The CSR activities by the multi-national oil companies in Nigeria was not impactful in spite of their implementation of the tenets of the sustainable development principles as proposed by prominent scholars in the extant literature (e.g. Carroll, 1979; Elkington, 2004; Aras \& crowther, 2009; Claydon, 2011). This vindicates the calls for a more insightful look at the process through which CSR implementation translates into performance. In essence, CSR is not just about implementation. It is also about making an impact which should translate into performance. The issue in the Nigerian petroleum industry highlights the inadequcy of the social responsiveness paradigm of CSR as noted by Wood (1991). There is need for a paradigm shift in CSR practice.

\section{Paradigm Shift in CSR Practice}

As noted earlier, the scholarly definitions of CSR reflected several perspectives. These perspectives are embedded within the paradigm shifts in the subject matter. The first paradigm was the capitalist paradigm. It reflected in the work of Smith (1776), where the argument was that businesses should be given a free hand to run their ventures in society so that they can make profit and spread the benefits in the long run (Smith, 1776). Businesses wielded so much power at this period and society saw business as a different entity. However, this paradigm was criticized with the emergence of seminal works that questioned the basis of the dichotomy between business and society, and argued that both spheres are inherently intertwined (Bowen, 1953; Kakabadse et al., 2005). At the same time, the effect of business on society became more intensive as society consistently suffered under the aggressive pursuit of profit without a corresponding contribution to society by businesses (Lantos, 2001; Kakabadse et al., 2005; Carroll, 1999; Claydon, 2011). The consciousness of the influence of the business activities on society increased with the calls for more responsibilities and obligations from business (Kakabadse et al., 2005). This saw the rise of the social obligation paradigm.

CSR in the social obligation paradigm was based on the argument that one of the obligations of businesses is to work towards making the society better (Fredrick, 1994). It all started with the work of Bowen (1953), where CSR was given a new conception as a normative approach that focused on the obligatory role of business in society (Moir, 2001). Unlike the profit based model of the capitalist paradigm, a social connotation was introduced to give CSR a socio-economic outlook. This gave a double bottom line to businesses (i.e. profit and social bottom lines). This need for the incorporation of a social bottom line was driven by the fact that at those times, businesses used to control the society while broadening their profit horizon and limiting the influence of others (Claydon, 2011). The influence of business was the fallout of the enormous power conferred on them in the capitalist paradigm. 
However, the call for social obligation by businesses was normative, which implied that businesses were expected to voluntarily contribute to society (Porter \& Kramer, 2006). This also meant that it was from their own decisions and initiatives that businesses decided to contribute to society. It was three emerging factors that had to do with stakeholders' perception of the increased political influence of businesses, the rising hegemonic tendencies by these businesses and the increased criticism from stakeholders about the activities of businesses that caused a shift from this paradigm (Claydon, 2011; Broomhill, 2007). Governments became more active in monitoring corporate behaviour to curb the excesses of businesses, while Global political bodies like the World Commission on Environment and Development (WCED), also known as the Brundtland Commission, emerged in the 1980s (Claydon, 2011). Due to these factors, control of businesses was entrenched and they were mandated to respond to the negative publicity surrounding their activities (Broomhill, 2007). The demands for responsiveness induced a paradigm shift from social obligatory requirements to a responsive based one. This was known as the social responsiveness paradigm.

As the social responsiveness paradigm emerged, the control of businesses through the establishment of global political bodies changed the dynamics in the relationship between business and society in terms of CSR. Society had more control over businesses through the global political bodies that were established (Claydon, 2011). Businesses were mandated by policies to respond to the economic, social and environmental spheres in society (Elkington, 2004). Series of environmental based legislations were derived from the Brundtland report which included the Framework on climate change; the convention on biological diversity; Agenda 21 and forest principles (Claydon, 2011). The central theme was the sustainability of both business and society through ensuring that socio-economic values are created for business and society in a way that environmental values are maintained for future generation of resources (Aras \& Crowther, 2009). In doing this, both business and society were expected to remain sustainable and were conceived not to distort the existence of each other.

One of the criticisms of this paradigm is focused on the fact that the means of the attainment of the conceived sustainable development was not captured in the responsiveness paradigm (Fredrick, 1994). This was ascribed to the prescriptive content of this paradigm (Claydon, 2011). The prescriptive content is evident in the policy based propositions for the implementation of CSR without concrete efforts towards finding out how these policies actually translate into performance (Porter \& Kramer, 2006; Basu \& Palazzo, 2008; Aras \& Crowther, 2009). More still, this paradigm ignored the interactive process between business and society in the form of factors that influences and shapes the actual implementation and outcome of CSR (Basu \& Palazzo, 2008). In other words, the creation of global regulatory bodies and the crafting of policies did not necessarily reflect in the actual implementation of CSR by companies.

Implementation of CSR goes beyond making policies and requires actual actions. Theoretically, some scholars have recognized this flaw and called for a performance based paradigm of CSR known as corporate social performance (Wartick \& Cochran, 1985; Wood, 1991). The lack of the practice of this performance based paradigm of CSR explains why companies seem responsive without generating performance. This is reflected in the case of the Nigerian petroleum industry.

The current CSR practice in the Nigerian petroleum industry is entrenched within the social responsiveness paradigm. This is evident in the fact that it has been noted that oil companies in Nigeria are relying on their global mandates and policy frameworks from the Nigerian government to implement CSR (Frynas, 2005). In doing this, these Oil Companies focus more on adhering to policies while ignoring the performance aspect of their CSR contributions, which often reflects in the failure of their attempts at creating value in their host-communities. While an adherence to the social responsiveness paradigm requires these Oil Companies to adhere to the mandate of embedding sustainable development practices in their activities, the social performance paradigm requires them to explore the nature of outcomes and the impact of these outcomes in the creation of value in their host-communities. In other words, these Oil Companies will need to go beyond the mere implementation of CSR towards exploring the real impact of their CSR initiatives.

The need for a shift in paradigm was noted by Frynas (2005) as the failure of these oil companies to involve the beneficiaries of their CSR initiatives. In essence, most of these CSR programs are conceived in air conditioned offices for host community beneficiaries who reside in the creeks. By doing this, the impact of the value instilled is not felt by members of the host-communities (Frynas, 2005). This is further reflected in some empirical studies where oil companies like Chevron has been found to donate more to areas that are deemed to be less important by stakeholders in the community (Alabi \& Ntukekpo, 2012). This goes to show that the oil companies seem more interested in contributing to society than identifying the outcome and performance of these contributions on the stakeholders in their host-communities. This article is proposing a paradigm shift to the 
performance based approach of CSR in practice. This is proposed as the solution to the gap between theory and practice in the attainment of sustainable development.

\section{Proposition of a Performance Based CSR Theory in Practice}

CSR theories that were developed with a performance based foundation can be found within the ethical theoretical perspective of CSR (Garriga \& Mele, 2004). The ethical theoretical perspective posited that the existence of businesses should be ethically based on value alignment with society (Garriga \& Mele, 2004). In CSR, this implies that business must consider the values that are inherent in society as the basis for their own contribution of value to society. Wood (1991) presented a theoretical framework upon which corporate social performance can be achieved. First, she related the dimensions in the pyramid of CSR (Carroll, 1991) with the principles of social legitimacy, public responsibility and managerial discretion. Secondly, she identified the processes of social responsiveness. Thirdly, she adopted Wartick \& Cochran's (1985) policies, which was an initial elaboration of social issues and reorganized them into outcomes of corporate behaviour (Carroll, 1999) to form her corporate social performance framework as indicated in Figure 4.

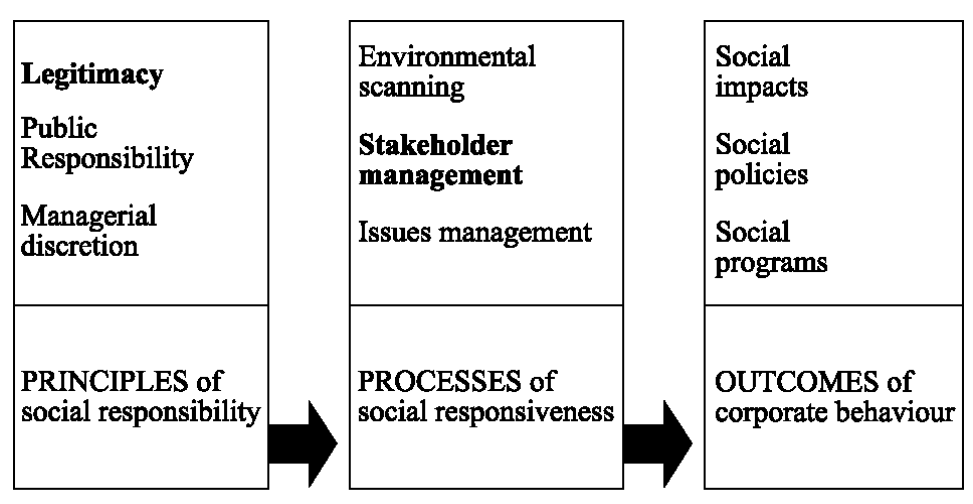

Figure 4. Corporate social performance framework wood (1991)

This implies that businesses must adopt the principles of social responsibility, establish and utilize processes to ensure social responsiveness, then generate outcomes for their corporate behaviour (Wood, 1991). While this has been noted in theory, it has not been widely implemented in business practice as can be seen from the Nigerian petroleum industry (Frynas, 2005). The practice of CSR by Oil Companies is limited to a show of understanding of the principles of social responsibility through social contributions to prove legitimacy, exhibition of public responsibility, and the employment of managerial discretion in the implementation of CSR (Frynas, 2005). In terms of process of social responsiveness, these companies care less about environmental scanning even though they boast of embarking on stakeholder and issues management (Frynas, 2005). Worst of all, they neglect the outcome of their corporate behaviour by not considering social impacts of their CSR, ignoring the effectiveness of their CSR programs and not collaborating with the stakeholders in their host-communities in crafting their social policies (Frynas, 2005).

In trying to practicalize a performance based CSR, it is important to explore the process through which the implementation of CSR transforms into outcomes, and how these outcomes reflects on performance. This has been noted in recent studies as the need to grasp the interaction effects that influences the relationship between business and society (Walker et al., 2010) and enhancing an understanding of the underlying process that drives the generation of returns from CSR (Bhattacharya et al., 2009). In essence, as much as it is important to adhere to the principles of social responsibility, it is also important to explore the interactive process that influences the relationship between business and society, and also enhance an understanding of the nature of outcomes from this process. An understanding of this process and outcome are important in creating a performance based CSR. Likewise, a performance based CSR is vital to the sustainability of business and society.

\section{Recommendations}

Three recommendations are made in this paper. These recommendations are made based on the existing theoretical and practical gaps that exist in the study of CSR. They are made as a means of attaining sustainable development through performance based CSR in the relationship between business and society. 
The first recommendation is based on the need for a paradigm shift in CSR practice by businesses, specifically the Multinational Oil Companies in the Nigerian petroleum industry. While they have done well in adopting the principles of social responsibility, they need to go beyond being responsive to generate performance from their implementation of CSR. As has been noted, the adherence to the principles of social responsibility should reflect on the sustainability of business and society. This is not the case in the Nigerian petroleum industry. For sustainable development to be attained by these Oil Companies, they must indulge in proper environmental scanning and explore the outcomes of their social responsibility so as to generate the needed performance.

Secondly, it is important to go beyond viewing CSR from a simplistic perspective. As has been analyzed earlier, most models of CSR did not explain the process of generating CSR outcomes (e.g. Carroll, 1991; Aras \& Crowther, 2009; Claydon, 2011). It is important to explore the interactive process through which the implementation of CSR transforms into outcomes (Bhattacharya et al., 2009; Walker et al., 2010). In essence, context specificity and environmental dynamics should be taken into consideration as suggested by current definitions of CSR (Freeman \& Hasnaoui, 2011; Gjolberg, 2009).

Finally, there is a need for empirical research in CSR to explore diverse concepts with respect to the interactive process in the generation of outcome from the implementation of CSR by businesses. There is lack of empirical study of this interactive process. Most studies in this area explore the impact of the implementation of CSR and consumers perception of CSR without looking at the antecedents to outcomes, and possible control variables (Kim \& Lee, 2012; Becker-Olsen, Andrew, \& Hill, 2006; Du, Bhattacharya, \& Sen, 2007; Ricks, 2005; Ellen, Webb, \& Mohr, 2000). Among other things, this will aid an understanding of the factors that affects CSR outcomes and the means through which performance can be attained through the implementation of CSR.

\section{Conclusions}

This paper has explored the gap between the theoretical connotation of sustainable development and its practical attainment in the relationship between business and society. In doing this, the context of the Nigerian petroleum industry was used. It was noted that sustainable development practice has been adopted by most Oil Companies in Nigeria, and that they are carried out through CSR. However, the implementation of CSR is not reflecting on the sustainable development of business and society in the industry. In search of the reasons behind this phenomenon, the theoretical evolution of CSR in definition, perspectives and paradigms was undertaken. It was realized that although the theoretical propositions in CSR has moved towards the corporate social performance paradigm, the practice of CSR, especially in the Nigerian petroleum industry, is still very much embedded within the social responsiveness paradigm. This explained why Oil Companies saw adherence to policies as being more important than the generation of outcome from the implementation of CSR.

To bridge this gap, it was noted that it is important for businesses to start looking beyond adherence to social responsibility. They need to look towards the exploration of the nature of outcomes generated. This was based on the reasoning that understanding the nature of outcomes would impact on the performance of CSR initiatives. To attain this understanding, three recommendations that include a shift to a performance based practice of CSR, a theoretical exploration of interactive process between business and society in CSR and the need for more empirical studies with focus on the interactive process were made in this paper. By adhering to the suggestions made in this paper, it is expected that there will be better understanding of the nature of outcomes from the implementation of CSR and how these outcomes can reflect in CSR performance for the sustainability of business and society.

\section{References}

Aghalino, S. O., \& Eyinla, B. (2009). Oil Exploration and Marine Pollution: Evidence from the Niger Delta, Nigeria. Journal of Human Ecology, 28(3), 177-182. Retrieved from http://www.krepublishers.com/02Journals/JHE/JHE-28-0-000-09-Web/JHE-28-3-000-09-Abst-PDF/JHE-28-03-177-09-1964-Aghalino-S-O/ JHE-28-03-177-09-1964-Aghalino-S-O-Tt.pdf

Alabi, O. F., \& Ntukekpo, S. S. (2012). Oil Companies and Corporate Social Responsibility in Nigeria: An Empirical Assessment of Chevrons Community Development Projects in the Niger Delta. British Journal of Arts and Social Sciences, 4(2), 361-374. Retrieved from http://www.bjournal.co.uk/paper/bjass_4_2/ bjass_04_02_18.pdf

Amadi, B. O., \& Abdullah, H. (2011). Evaluating Multi-Sector Partnerships for Sustainable Community Development in Nigeria. Canadian Social Science, 7, 272-279. http://dx.doi.org/10.5539/ass.v8n4p57

Aras, G., \& Crowther, D. (2009). Corporate Sustainability Reporting: A Study in Disingenuity. Journal of Business Ethics, 87(1), 279-288. http://dx.doi.org/10.1007/s10551-008-9806-0 
Babatunde, A. O. (2012). An Analytical Evaluation of the Cost of the Conflict in Nigeria's Niger Delta. Journal of Confliction, 3(1), 50-58. http://dx.doi.org/10.7238/joc.v3i1.1327

Basu, K., \& Palazzo, G. (2008). Corporate Social Responsibility: A Process Model of Sense-making. Academy of Management Review, 33, 122-136. http://dx.doi.org/10.5465/AMR.2008.27745504

Becker-Olsen, K. L., Andrew, B., \& Hill, R. P. (2006). The Impact of Perceived Corporate Social Responsibility on Consumer Behaviour. Journal of Business Research, 59(1), 46-53. http://dx.doi.org/10.1016/j.jbusres. 2005.01.001

Berle, A. A. (1932). Corporate Powers as Powers in Trust. Harvard Law Review, 44, 1049-1074. http://dx.doi.org/10.2307/1331341

Bhattacharya, C. B., Korschun, D., \& Sen, S. (2009). Strengthening Stakeholder-Company Relations through Mutually Beneficial Corporate Social Responsibility Initiatives. Journal of Business Ethics, 85(2), 257-272. http://dx.doi.org/10.1007/s10551-008-9730-3

Bowen, H. (1953). Social Responsibilities of the Businessman. NY: Harper \& Row.

Broomhill, R. (2007). Corporate Social Responsibility: Key Issues and Debates. Retrieved from http://firgoa.usc.es/drupal/files/Ray_Broomhill.pdf

Carroll, B. A. (1991). The Pyramid of Corporate Social Responsibility: Toward the Moral Management of Organizational Stakeholders. Business Horizons, 34, 39-49. http://dx.doi.org/10.1016/0007-6813(91) 90005-G

Carroll, B. A. (1979). A Three Dimensional Conceptual Model of Corporate Performance. Academy of Management Review, 4(4), 497-505. http://dx.doi.org/10.5465/AMR.1979.4498296

Carroll, A. B., \& Buchholtz, A. K. (2012). Business and Society: Ethics and Stakeholder Management. Ohio: South-Western Cengage Learning.

Chukwuemeka, E. E. \& Aghara, V. N. O. (2010). Niger-Delta Youth Restiveness and Socio-Economic Development in Nigeria. Educational Research and Reviews, 5(7), 400-407.

Clark, J. M. (1926). Social Control of Business. Chicago: University of Chicago Press.

Claydon, J. (2009). Two Models of CSR and Sustainability: A Comparison between the Pyramid of Corporate Social Responsibility and the Model of Sustainable Development. Issues in Social and Environmental Accounting, 2(2), 260-265.

Dahlsrud, A. (In press). How Corporate Social Responsibility is Defined: An Analysis of 37 Definitions. Corporate Social Responsibility and Environmental Management, 15, 1-13. http://dx.doi.org/10.1002/ csr.132

Du, S., Bhattacharya, C. B., \& Sen, S. (2011). Corporate Social Responsibility and Competitive Advantage: Overcoming the Trust Barrier. Management Science, 57(9), 1528-1545. http://dx.doi.org/10.1287/ mnsc. 1110.1403

Earth Policy Institute. (2013). Eco-economy Indicators: Carbon Emissions. Retrieved from http://www.earth-policy.org/indicators/C52

Eells, R. (1956). Corporation Giving in a Free Society. New York: Harper \& Brothers.

Egberongbe, F. A. O., Nwilo, P. C., \& Badejo, O. T. (2006). Oil Spill Disaster along Nigerian Coastlines. 5th FIG Regional Conference on Promoting Land Administration and Good Governance, 1-26. Retrieved from https://www.fig.net/pub/accra/papers/ts16/ts16_06_egberongbe_etal.pdf

Elkington, J. (2004). Enter the Triple Bottom Line. The Triple Bottom Line: Does it all add up? Assessing the Sustainability of Business and CSR. London: Earthscan Publications Ltd. Retrieved from http://kmhassociates.ca/resources/1/Triple\%20Bottom\%20Line\%20a\%20history\%201961-2001.pdf

Ellen, P. S., Webb, J. D., \& Mohr, A. L. (2006). Building Corporate Associations: Consumer Attributions for Corporate Socially Responsible Programs. Journal of Academy of Marketing Science, 34(2), 147-157. http://dx.doi.org/10.1177/0092070305284976

Epstein, E. M. (1987). The Corporate Social Policy Process: Beyond Business Ethics, Corporate Social Responsibility, and Corporate Social Responsiveness. California Management Review, 29, 99-114. http://dx.doi.org/10.2307/41165254 
Estes, R. J. (1993). Toward Sustainable Development: From Theory to Praxis. Social Development Issues, 15, $1-29$.

ExxonMobil. (2012). Corporate Citizenship Report. Retrieved from http://cdn.exxonmobil.com/ /media/ Reports/Corporate\%20Citizenship\%20Report/2012/news_pub_ccr2012.pdf

Frederick, W. C. (1960). The Growing Concern over Business Responsibility. California Management Review, 2 , 54-61. http://dx.doi.org/10.2307/41165405

Freeman, I., \& Hasnaoui, A. (2011). The Meaning of Corporate Social Responsibility: The Vision of Four Nations. Journal of Business Ethics, 11, 419-443. http://dx.doi.org/10.1007/s10551-010-0688-6

Friedman, M. (1962). Capitalism and Freedom. Chicago: University of Chicago Press.

Frynas, J. G. (2003). Global Monitor: Royal Dutch/Shell. New Political Economy, 8(2), $275-285$. http://dx.doi.org/10.1080/13563460307169

Garriga, E., \& D. Mele. (2004). Corporate Social Responsibility Theories: Mapping the Territory. Journal of Business Ethics, 53, 51-71. http://dx.doi.org/10.1023/B:BUSI.0000039399.90587.34

Gjolberg, M. (2009). Measuring the Immeasurable? Constructing an Index of CSR Practices and CSR Performance in 20 countries. Scandinavian Journal of Management, 25, 10-12.

Ibok, E. E., \& Mboho, K. S. (2011). Corporate Social Responsibility Towards Host-Communities in Nigeria: Focus on ExxonMobil in Akwa Ibom State. Journal of Sociology, Psychology and Anthropology in Practice, 3(1), 110-119.

Jike, V. T. (2004). Environmental Degradation, Social Disequilibrium, and the Dilemma of Sustainable Development in the Niger-Delta of Nigeria. Journal of Black Studies, 34(5), 686-701. http://dx.doi.org/10.1177/0021934703261934

Jones, T. M. (1983). An Integrating Framework in Business and Society: A Step Towards an Elusive Paradigm? Academy of Management Review, 8, 559-564. http://dx.doi.org/10.5465/AMR.1983.4284653

Johnson, H. L. (1971). Business in Contemporary Society: Framework and Issues. CA: Wadsworth.

Kakabadse, K. N., Rozuel, C., \& Davis, L. (2005). Corporate Social Responsibility and Stakeholder Approach: A Conceptual Review. International Journal of Business Governance and Ethics, 1(4), $277-302$. http://dx.doi.org/10.1504/IJBGE.2005.006733

Kim, S., \& Lee, Y. J. (2012). The Complex Attribution Process of CSR Motives. Public Relations Review, 38(1), 168-170. http://dx.doi.org/10.1016/j.pubrev.2011.09.024

Kreps, T. J. (1940). Measurement of Social Performance of Business In An Investigation of Economic Power for the Temporary Economic Committee (Monograph No.7). Washington D.C.: US Government Printing Press.

Lantos, G. P. (2001). The Boundaries of Strategic Corporate Social Responsibility. Journal of Consumer Marketing, 18(7), 595-630. http://dx.doi.org/10.1108/07363760110410281

Levitt, T. (1958). The Dangers of Social Responsibility. Harvard Business Review, 36, 41-50.

Moir, L. (2001). What Do We Mean by Corporate Social Responsibility? Corporate Governance, 14, 16-22. http://dx.doi.org/10.1108/EUM0000000005486

The New York Times. (2010). Far From Gulf, A Spill Scourge 5 Decades Old. Retrieved from http://www.nytimes.com/2010/06/17/world/africa/17nigeria.html?_r=0

Opukri, C. O., \& Ibaba, S. I. (2008). Oil Induced Environmental Degradation and Internal Population Dispalcement in the Nigeria's Niger-Delta. Journal of Sustainable Development in Africa, 10(1), 173-193.

Paki, F. A. E., \& Ebienfa, K. I. (2011). Militant Oil Agitations in Nigeria's Niger Delta and the Economy. International Journal of Humanities and Social Science, 1(5), 140-145.

Porter, M. E., \& Kramer, M. R. (2006). Strategy \& Society: The Link between Competitive Advantage and Corporate Social Responsibility. Harvard Business Review, 84(12), 78-92.

Scherer, A. G., \& Palazzo, G. (2007). Toward a Political Conception of Corporate Responsibility: Business and Society Seen from a Habermasian Perspective. Acad. Manag. Rev., 32, 1096-1120. http://dx.doi.org/10.5465/AMR.2007.26585837

Ricks, J. M. (2005). An Assessment of Strategic Corporate Philanthropy on Perceptions of Brand Equity Variables. Journal of Consumer Marketing, 22, 121-134. http://dx.doi.org/10.1108/07363760510595940 
Steurer, R., Langer, M. E., Konrad, A., \& Martinuzzi, A. (2005). Corporations, Stakeholders and Sustainable Development: A Theoretical Exploration of Business-Society Relations. Journal of Business Ethics, 61(3), 263-281. http://dx.doi.org/10.1007/s10551-005-7054-0

Uyigue, E., \& Agho, M. (2007). Coping with Climate Change and Environmental Degradation in the Niger Delta of Southern Nigeria. Community Research and Development Centre (CREDC) Nigeria. Retrieved from http://priceofoil.org/content/uploads/2007/06/07.06.11\%20-\%20Climate_Niger_Delta.pdf

Wartick, S. L., \& Cochran, P. (1985). The evolution of the Corporate Social Performance Model. The Academy of Management Review, 10(4), 758-769. http://dx.doi.org/10.2307/258044

Wood, D. (1991). Corporate Social Performance Revisited. The Academy of Management Review. Working paper, 16(4), 691-718. http://dx.doi.org/10.2307/258977

\section{Copyrights}

Copyright for this article is retained by the author(s), with first publication rights granted to the journal.

This is an open-access article distributed under the terms and conditions of the Creative Commons Attribution license (http://creativecommons.org/licenses/by/3.0/). 